\section{New position for subdermal implant}

Since the change in guidance to positioning subdermal implants over the triceps, ${ }^{1}$ myself and colleagues in our role as implant fitters have been aware of an increasing number of women contacting our service soon after implant insertion to express their dissatisfaction with the new insertion site. The main complaints have been that the implant 'catches' on clothing, aches, and causes sharp pains particularly on movement. Many of these women request implant removal, despite having been happy with a previous implant. In November 2020 we started to collate these presentations for implant removal and already have a list comprising 15 women.

All our implant fitters have years of experience and have all received training on the new insertion site. However, in supervision sessions, many have also expressed a loss of confidence in inserting. The new site makes it more awkward and difficult to visualise the area while inserting, and the different consistency of the skin has resulted in nurses feeling that they are inserting slightly deeper than previously. The position in the arm also makes the implant less accessible for removal, particularly with regard to lifting the distal tip of the implant for removal when sited over the triceps.

We wonder whether other services have had a similar experience or response from women following implant insertion?

\section{Jane Cromarty 1}

Sexual Health Dorset, Dorset Healthcare University NHS Foundation Trust, Dorset, UK

Correspondence to Jane Cromarty, Sexual Health Dorset, Dorset Healthcare University NHS Foundation Trust, Poole, UK; Jane.cromarty@nhs.net

Funding The authors have not declared a specific grant for this research from any funding agency in the public, commercial or not-for-profit sectors.

Competing interests None declared.

Patient and public involvement Patients and/or the public were not involved in the design, or conduct, or reporting, or dissemination plans of this research.

Provenance and peer review Not commissioned; internally peer reviewed.

(C) Author(s) (or their employer(s)) 2021. No commercial re-use. See rights and permissions. Published by BMJ.
Check for updates

Published Online First 4 February 2021

BMJ Sex Reprod Health 2021;47:231.

doi:10.1136/bmjsrh-2021-201029

\section{ORCID iD}

Jane Cromarty http://orcid.org/00000002-9789-4682

\section{REFERENCE}

1 FSRH. FSRH CEU statement on Nexplanon ${ }^{\circledR}$ insertion site 15 January 2020, 2020. Available: https://www.fsrh. org/standards-and-guidance/documents/ fsrh-ceu-statement-on-nexplanoninsertion-site-15-january-2020/ 